\title{
DEVELOPMENT OF FOOD SECURITY INFORMATION SYSTEM BASED ON BUSINESS INTELLIGENCE IN FOOD SECURITY AGENCY, MINISTRY OF AGRICULTURE, INDONESIA
}

\author{
Manise Hendrawaty ${ }^{1}$; Harisno ${ }^{2}$ \\ MMSI Post Graduate Department, Faculty of Information system management, \\ Bina Nusantara University Jl KH Syahdan 9, Jakarta 11480, Indonesia, \\ 1maniez.hendrawaty@gmail.com ²harisno@address.edu
}

\begin{abstract}
Food is the main basic need of human, because of that fulfillment of human need of food has to be fulfilled. So it can fulfill that need, then government institution, Food Security Agency (BKP) is formed so it can monitor fulfillment of food need of society. The goals of this writing are to develop food security information system that provides dashboard facility based on business intelligence, to develop food security information system that can give fast, precise and real time information about food security, to develop decision-making support system for chairman in food security institution. Data is obtained from questionnaires to 51 respondents that are chairmen in Food Security Agency. Data is analyzed with SWOT analysis method for business environment and IT balanced scorecard (IT BSC) for IS/IT environment. The result of analysis of food security information system in Food Security Agency can help chairman in decision-making by presenting information about dashboard that gives fast, precise and real time information. It can be concluded that development of information is successfully done.
\end{abstract}

Keywords: Business Intelligence; Information System; Decision-Making Support System

\section{INTRODUCTION}

Food is the main basic need of human, because of that fulfillment of human need of food has to be fulfilled. So, it can fulfill that need, then Food Security Agency (BKP) that is government institution below ministry of agriculture Indonesia that is formed through Keppres No. 136 year 1999 is expected to be able to fulfill that demand according to its main task and function, which are implementing assessment, development and coordination in food security, altogether with other related institution in stabilizing food security especially in increasing acceleration of food diversification and stabilizing food security of society (strategic planning of Food Security Agency 2010-2014).

The main pillars that determine food security are availability of food stock, distribution of food, and diversification of food consumption. Remembering the importance of fulfilling food sufficiency, each country prioritizes development of food security as foundation for development of other sectors. Development of food security in Indonesia is aimed to guarantee sufficient, safe, quality, nutritious, and balanced availability and food consumption in domestic, regional, national level, all the time and evenly.
To be able to support task and function of BKP Ministry of Agriculture Indonesia, institution needs an information system that can provide information in form of dashboard that is related to information of food availability and vulnerability, food distribution and reserve, diversification of consumption and food security, where the three integration result produces map of food vulnerability that pictures region in Indonesia that experiences food vulnerability as effect of unevenly food distribution in region. Therefore institution can directly making decision to give several types of help in accordance with food need in local area through available distribution lane quickly and precisely.

Fulfilling information need in form of that dashboard can be fulfilled by developing information system of food availability and vulnerability, food distribution and reserve, and diversification of consumption and food security based on Business Intelligence (BI). With $\mathrm{BI}$, it will help BKP in increasing quality of taking strategic decision and can predict condition of food security in future.

The problems that are in BKP Ministry of Agriculture of Indonesia are: (1) How to develop food security information system to know a region experiencing food vulnerability, as the effect of 
difficulty in accessing food from food sources and distributing it to society, that is shown by dashboard panels from that system as early warning sign for getting special treatment in mitigation and recovery a region experiencing food vulnerability? (2) How to develop food security information system that can give information related to fast, precise and real time food security to be used by chairman in making program plan, determining target, strategy and intervention of food vulnerability? (3) How to develop food security information system that can be used by chairman in giving decision to directly give several types of help in accordance with food need in local area through available distribution lane quickly and precisely in case of a region that experiences food vulnerability?.

According to problems that have been elaborated before, then the goals of thesis writing with internship project (IP) lane are: to develop food security information system that provides dashboard facility based on Business Intelligence (BI) that allows chairman to know a region experiencing food vulnerability, as the effect of difficulty in accessing food from food sources and distributing it to society, that is shown by dashboard panels from that system as early warning sign for getting special treatment in mitigation and recovery a region experiencing food vulnerability, to develop food security information system based on BI that can give fast, precise and real time information about food security to be used by chairman in making program plan, determining target, strategy and intervention of food vulnerability, in case of a region that experiences food vulnerability, then chairman can give decision to directly give several types of help in accordance with food need in local area through available distribution lane quickly and precisely.

The benefits from this research are: there is availability of dashboard from food security information system based on BI that allows chairman to know a region experiencing food vulnerability, as the effect of difficulty in accessing food from food sources and distributing it to society, that is shown by dashboard panels from that system as early warning sign for getting special treatment in mitigation and recovery a region experiencing food vulnerability. There is availability of food security information system based on BI that can give fast, precise and real time information about food security to be used by chairman in making program plan, determining target, strategy and intervention of food vulnerability. In case of a region that experiences food vulnerability, then chairman can give decision to directly give several types of help in accordance with food need in local area through available distribution lane quickly and precisely.

Development of system based on Business Intelligence certainly has been done by previous research. Development of system by making dashboard to present information will ease executive in doing decision-making compared to must see detail data in large quantity.

Organization can reach business success by implementing Business Intelligence because BI is not only for internal organization process, but also for external environment that is mutually competitive, implementing BI is a new opportunity and possibility for organization to develop [1].

Ref. [2] states that condition of economy now, each organization wants to cut expense and do investment wisely in its business. Eaxh organization focuses on developing efficiency in its operational by doing analysis on historical data that is as good as condition now so executive can make decision based on startegy that they have. Information is the most valuable asset in BI or data ware house because that information can help decision-making that can increase profit in business.

In organization that implements $\mathrm{BI}$, allows organization to make real time decision because BI can integrate all organization needs so executive can get fast information [3]

The profit of development of system is based on Business Intelligence, according to Ref. [2]. BI is used by management, businessman that helps them in making decision to support business growth and is still on top of business competition [4-17].

Analysis method that is used in this writing is divided into three, which are:

1. Business environment analysis method

Business environment analysis is done by using SWOT analysis and Current process analysis (CRUD Matrix)

2. IS/It environment analysis method

IS/It environment analysis is done by using IT Balanced Scorecard (IT BCS) and portfolio application analysis.

Method of system development that is done in this writing is by using method of Vercellis concept theory [4], where the steps of development are:

1. Analysis
a. Identification of Business Needs

2. Design

a. Infrastructure Recognition

b. Project Macro Planning

3. Planning

a. Detailed Project requirements

b. Definition of the Mathematical Models Needed

c. Identification of the Data Definition of Data Warehouses and Data Marts

d. Development of a Protoype

4. Implementation and Control

a. Development of Data Warehouses and Data Marts

b. Development of ETL Tools 
c. Development of Metadata

d. Development of Applications

e. Release and Testing

Method of system development evaluation

1. TAM method

In TAM method, there are 4 perspectives that are used as evaluation material of development of information system, which are:

a. Attitude Toward Using (ATU), attitude of user that can be in form of acceptance or rejection in using information system application.

b. Behavioral Intention to Use (ITU), attitude of user to still use information system application.

c. Perceived Ease of Use (PEOU), viewpoint of users about easiness in using information system application, easy to be understood, learnt and used.

d. Perceived Usefulness (PU), user's trust on information system application that can give benefit in its usage.

e. Actual Use (AU), frequency of how often user uses information system application.

2. Pre-Post Test

Pretest - posttest is used in research of attitude, the main goal is to compare/ measure the change in result of done experiment. The result from this pretest-posttest will show gain or difference between conditions before experiment is done and after the experiment is done.

Data collecting method

1. Primary data

The primary data are:

\section{a. Interview}

Writer will present several questions to related parties that are available in Food Security Agency in Ministry of Agriculture of Indonesia related with system of availability, distribution, vulnerability and diversification of food consumption that is running now. As well as presenting question related with information that is needed by executive that is used as support material in making decision so writer can present recommendation for strategic information system planning in future.

b. Observation

Writer observes directly on process that happens in Food Security Agency and notes things that are related with problem discussion in this internship project.

c. Questionnaire

Writer hands out questionnaire to chairman in Food Security Agency related with available IS/IT now and development of system that has been done.

2. Secondary data

Secondary data that are used in this internship project are:

a. Library study

Writer does data collecting by studying and collecting theoretical data based on reference books and journal that relate to food security in this internship project.

Framework that is contained in this writing can be seen on figure 1 .

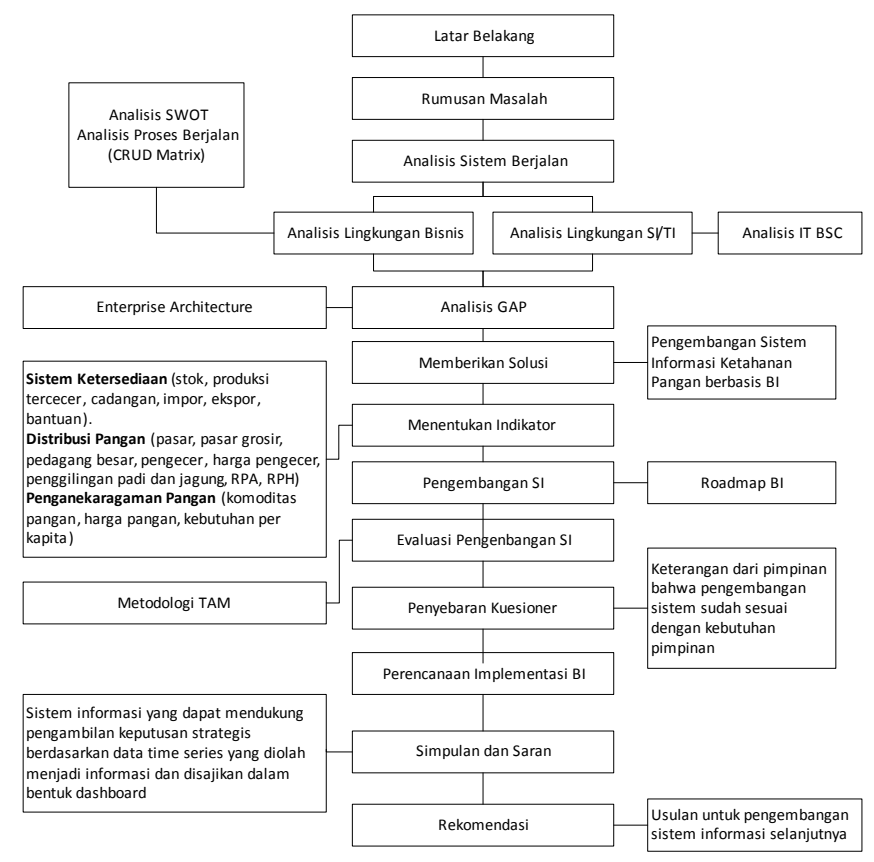

Fig. 1: Framework 
Framework in this internship writing is:

1. Know the background of institution that will be become object in internship project, along with its task and function.

2. Formulate available problem that is in institution poured in form of question.

3. Analyze current system. System analysis that is running is analyzed from business aspect and IS/IT role that is available in institution.

4. Based on analysis between business environment and IS/IT environment, it is found that there is GAP between current condition and target from information system that is hoped. Then GAP analysis is done.

5. From the result of GAP analysis and analysis of business and IS/IT environment, then in the fifth step it is found solution to develop food security information system based on BI.

6. To be able to do development of information system, it needs to know indicator that is key performance indicator in developing that information system. For that, indicator which will be used in developing that information system is determined.

7. After determining variable, development of information system based on BI is conducted to solve problem that is formulated.
8. Development of system that has been made will be evaluated to find out the system and business correlation.

9. To find out the result of development of system that has been made has fulfilled chairman's need as supporting tool for decision-making then questionnaire is handed out to chairmen related with the result of development of that system.

10. Making BI implementation plan based on analysis and model, as well as prototype that has been made.

11. Make conclusion and suggestion on whole content of this internship project writing. Where hoped conclusion is result of development of information system can help chairman in decision-making.

12. Give suggestion related to development of information system that can be developed next.

\section{RESULTS AND DISCUSSION}

Business process of Food Security Agency now can be seen on Figure 2.

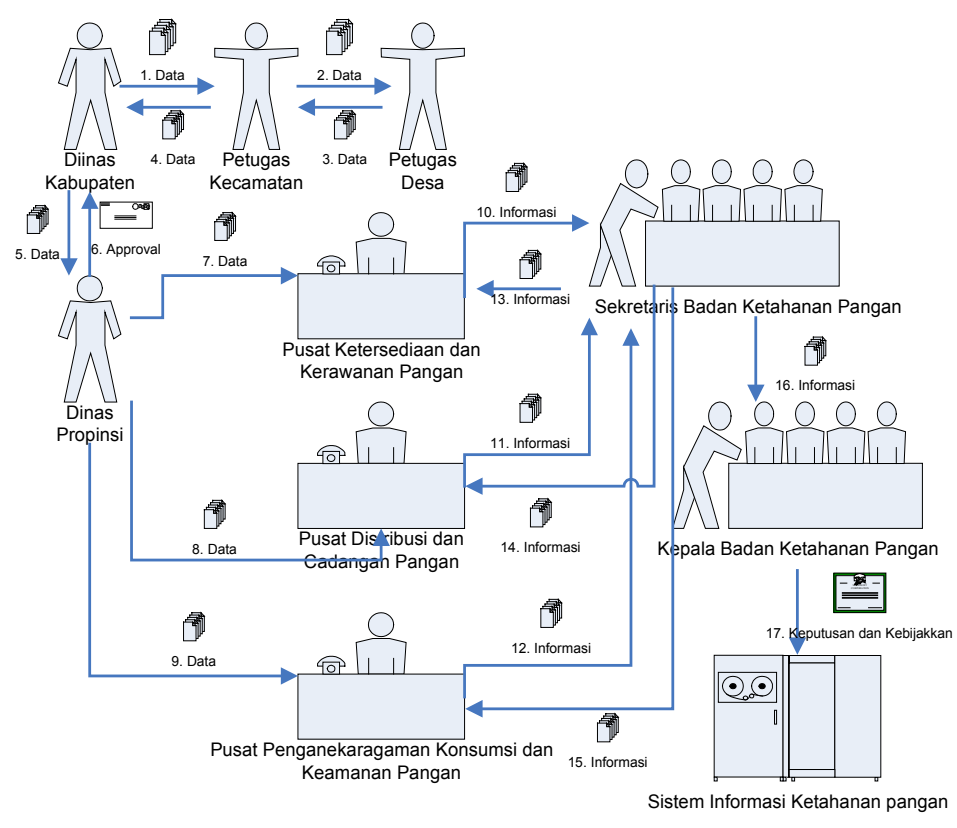

Fig. 2: Business process of Food Security Agency

Development of system that is done in accordance with steps of developing system based on $\mathrm{BI}$ consists of:

\section{Analysis phase \\ Analysis of business environment using SWOT analysis while IS/It environment}

analysis using IT Balanced Scorecard (IT BSC) analysis.

\section{SWOT Analysis}

In this phase, it is done an analysis related to internal and external factor of company, where internal factor consists of strength and weakness, while external factor consists of threat and opportunity. 


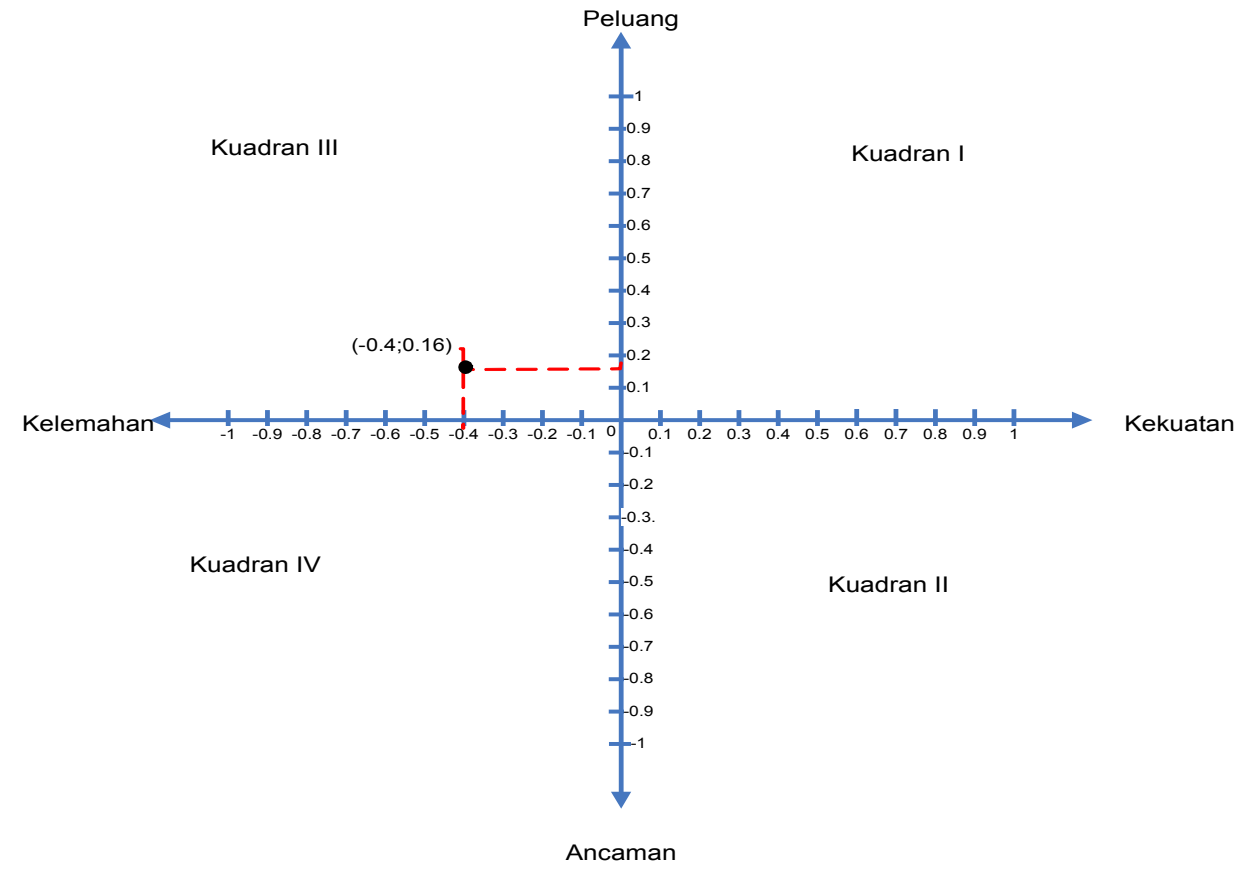

Fig. 2: Business process of Food Security Agency

Figure 3 shows BKP is in quadrant III (W-O) where institution has to increase opportunity to minimize weakness. The result of SWOT analysis is drawn in form of table which can be seen on table 1 .

Table 1: SWOT Matrix

\begin{tabular}{|c|c|c|}
\hline & Strengths S1, S2, S3, S4, S5, S6, S7, S8 & $\begin{array}{l}\text { Weakness W1, W2, W3, W4, W5, W6, W7, W8, W9, } \\
\text { W10 }\end{array}$ \\
\hline & S-O strategy & W-O strategy \\
\hline \multirow[t]{2}{*}{$\begin{array}{l}\text { Opportunities } \\
\text { O1, O2, O3, O4, O5, O6, } \\
\text { O7 }\end{array}$} & $\begin{array}{l}\text { 1. Developing newest information technology } \\
\text { to increase effectiveness and efficiency in } \\
\text { fulfilling need of qualified data and information } \\
\text { related to information of food availability and } \\
\text { vulnerability, food distribution and reserve, } \\
\text { and diversification of consumption and food } \\
\text { security (S1-O7, S5-O2). } \\
\text { 2. Developing an information system that } \\
\text { can integrate realtime data and information } \\
\text { between central and regional to obtain } \\
\text { information related to food availability and } \\
\text { vulnerability, food distribution and reserve, } \\
\text { and diversification of consumption and food } \\
\text { security currently.(S3-O6) }\end{array}$ & $\begin{array}{l}\text { 1. Developing food security information system in } \\
\text { form of dashboard panels as early warning sign to } \\
\text { get special treatment in mitigation and recovery of } \\
\text { region that is food shortage. (W5-O2, W2-O3) } \\
\text { 2. Developing food security information system that } \\
\text { can give fast, precise and real time information } \\
\text { of food security in arranging program plan, } \\
\text { determining target, strategy and intervention of } \\
\text { food vulnerability by chairman. (W3-O1, W2-O5). } \\
\text { Developing a food security information system that } \\
\text { can support chairman's decision-making to give } \\
\text { help in accordance with food need through fast and } \\
\text { precise distribution lane. (W7-O4, W9-O3) }\end{array}$ \\
\hline & S-T strategy & W-T strategy \\
\hline $\begin{array}{l}\text { Threats T1, T2, T3, T4, T5, T6, } \\
\text { T7, T8, T9, T10 }\end{array}$ & $\begin{array}{l}\text { 1. Arranging method that can be used to review data } \\
\text { to be information that is easy to be utilized related } \\
\text { user to get information about food availability and } \\
\text { vulnerability, food distribution and reserve, and } \\
\text { diversification of consumption and food security. (S4- } \\
\text { T11,S3-T8,S7-T2) } \\
\text { 2. Arranging food security information system that can } \\
\text { be utilized to decrease food and nutrient vulnerability } \\
\text { level by utilizing data and information related with } \\
\text { food availability and vulnerability, food distribution } \\
\text { and reserve, and diversification of consumption and } \\
\text { food security (S2-T10, S4-T4) }\end{array}$ & $\begin{array}{l}\text { 1. Building an information system that can increase } \\
\text { uniformity of data and information management in regional } \\
\text { with the central so it produces information and data } \\
\text { management related to food availability and vulnerability, } \\
\text { food distribution and reserve, and diversification of } \\
\text { consumption and food security. (W2-T10, W6-T10, W3- } \\
\text { T7) } \\
\text { 2. Decreasing food and nutrient level with better information } \\
\text { through collecting and processing raw data. (W1-T9) } \\
\text { 3. Doing promotion about food security program to attract } \\
\text { investor's interest. (W8-T2, W3-T6) }\end{array}$ \\
\hline
\end{tabular}




\section{IT BSC Analysis}

IT BCS analysis consists of 4 perspectives that are seen from IT point of view, including: institution contribution, user orientation, operational refinement, and future orientation. The result of each perspective can be seen on table 2 .

Table 2: IT BSC

\begin{tabular}{|c|c|c|}
\hline IT BSC & Strategy & Goal of strategy \\
\hline $\begin{array}{l}\text { Institution } \\
\text { contribution }\end{array}$ & $\begin{array}{l}\text { Developing SIKP in } \\
\text { form of dashboard } \\
\text { panels that provide fast, } \\
\text { precise, and accurate } \\
\text { information as support } \\
\text { of decision-making }\end{array}$ & $\begin{array}{l}\text { As early warning of food } \\
\text { vulnerability region, } \\
\text { arranging program, and } \\
\text { determining strategy and } \\
\text { can support strategic } \\
\text { decision-making }\end{array}$ \\
\hline User orientation & $\begin{array}{l}\text { Knowing information } \\
\text { of food vulnerability } \\
\text { region early based on } \\
\text { information that has } \\
\text { been processed to be } \\
\text { knowledge }\end{array}$ & $\begin{array}{l}\text { As prevention of early } \\
\text { food vulnerability that is } \\
\text { obtained from historical } \\
\text { data. }\end{array}$ \\
\hline $\begin{array}{l}\text { Operational } \\
\text { refinement }\end{array}$ & $\begin{array}{l}\text { Maintaining and } \\
\text { developing fast, } \\
\text { precise, and real time } \\
\text { SIKP }\end{array}$ & $\begin{array}{l}\text { So that information } \\
\text { system that is used } \\
\text { can run efficiently and } \\
\text { effectively }\end{array}$ \\
\hline Future orientation & $\begin{array}{l}\text { Developing reserve } \\
\text { information system, } \\
\text { price stability and food } \\
\text { security }\end{array}$ & $\begin{array}{l}\text { Continuing activity that } \\
\text { can be done by BKP } \\
\text { in order to overcome } \\
\text { vulnerability that will } \\
\text { happen after getting } \\
\text { information }\end{array}$ \\
\hline
\end{tabular}

\section{Design Phase}

In this phase, it gives information related with fields that involve in developing information system, which is: food availability, food distribution and food consumption. Integration of these three will give output of food vulnerability region that is drawn with color in that vulnerable area. Color indicator can be seen in table 3 .

Table 3: Indicator of food vulnerability

\begin{tabular}{llcl}
\hline \multicolumn{1}{c}{ Color } & $\begin{array}{c}\text { Color } \\
\text { meaning }\end{array}$ & $\begin{array}{c}\text { Net of availability } \\
\text { (Ton) }\end{array}$ & \multicolumn{1}{c}{ description } \\
\hline Scarlet & 1st priority & $0-200.000$ & Really vulnerable \\
Red & 2nd priority & $201.000-400.00$ & Fairly vulnerable \\
Pink & 3rd priority & $401.000-600.00$ & Vulnerable alert \\
Light green & 4thpriority & $601.000-800.00$ & Fairly safe \\
Green & 5th priority & $801.000-1.000 .000$ & Safe \\
Dark green & 6thpriority & $>1.000 .000$ & Really safe \\
& & & \\
\hline
\end{tabular}

Planning Phase

In this phase, it consists of mathematics logic that is used to obtain information of region that experience food vulnerability. Where the mathematic model is as following a. Net availability of rice

$$
\begin{aligned}
& R_{n e t}=P_{n e t} * c \\
& P_{n e t}=p-(s+f+w) \\
& \text { pnet }=P-((P * 0.9 \%)+(P * 0.4 \%)+(P * 5.4 \%))
\end{aligned}
$$

Description:

(Rnet) = net of rice production (in Ton)

(Pnet) = net of availability (in Ton)

$\mathrm{P} \quad=$ gross of production (in Ton)

(c) $=$ conversion factor $(62.74 \%)$

(s) $\quad=$ seed data (in $\mathrm{Kg}$ )

(f) $\quad=$ feed (in $\mathrm{Kg}$ )

(w) = scattered (in $\mathrm{Kg}$ )

(Source: Food Security Agency, 2013)

b. Net availability of maize

$$
\begin{aligned}
& \text { Mnet }=M-(s+f+w) \\
& \text { Mnet }=M-((M * 0.9 \%)+(M * 6 \%)+(M * 5 \%))
\end{aligned}
$$

Description:

(Mnet) = net of maize production (in Ton)

$\mathrm{M} \quad=$ gross of maizeproduction (in Ton)

(s) $\quad=$ seed data (in $\mathrm{Kg}$ )

(f) $\quad=$ feed (in $\mathrm{Kg}$ )

(w) = scattered (in $\mathrm{Kg}$ )

(Source: Food Security Agency, 2013)

c. Net availability of sweet potato

$S P=S P-(f+w)$

$S P_{n e t}^{\text {net }}=S P-\left(\left(S P^{*} 2 \%\right)+\left(S P^{*} 10 \%\right)\right.$

Description:

(SPnet) $=$ net of sweet potato production (in Ton)

$\mathrm{SP} \quad=$ gross of sweet potato production (in Ton)

(f) $\quad=$ feed (in $\mathrm{Kg}$ )

(w) = scattered (in $\mathrm{Kg}$ )

(Source: Food Security Agency, 2013)

d. Net availability of cassava

$C_{\text {net }}=C-(f+w)$

$C_{n e t}=C-((C * 2 \%)+(C * 2.13 \%)$

Description:

(Cnet) = net of cassava production (in Ton)

$\mathrm{C}=$ gross of cassava production (in Ton)

(f) $\quad=$ feed (in $\mathrm{Kg}$ )

(w) = scattered (in $\mathrm{Kg})$

(Source: Food Security Agency, 2013)

\section{Implementation and Control Phase}

In this phase, it shows the result from development of information system that is developed in Food Security Agency. 


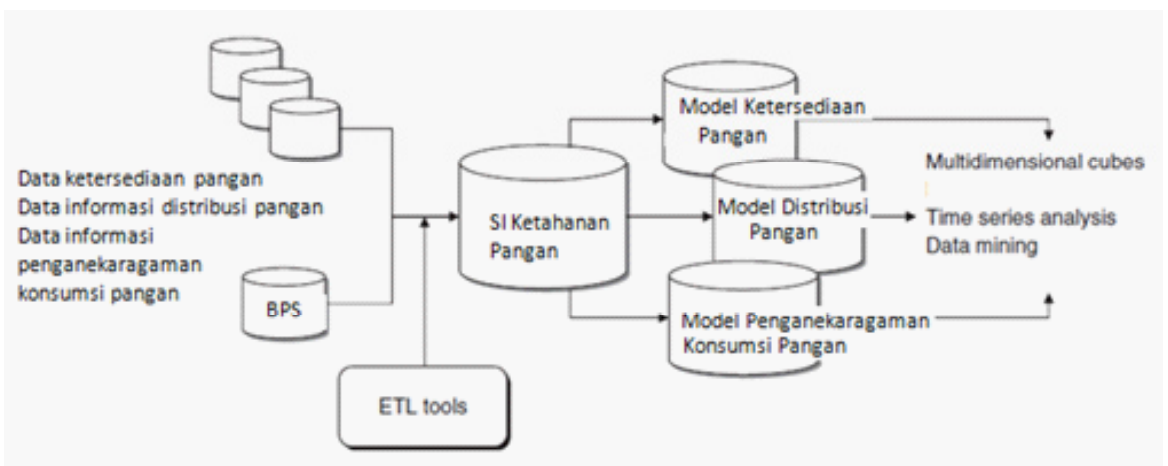

Fig. 4: Business Intelligence architectural of food security information system

The result of map of food vulnerability can be seen on figure 5 .

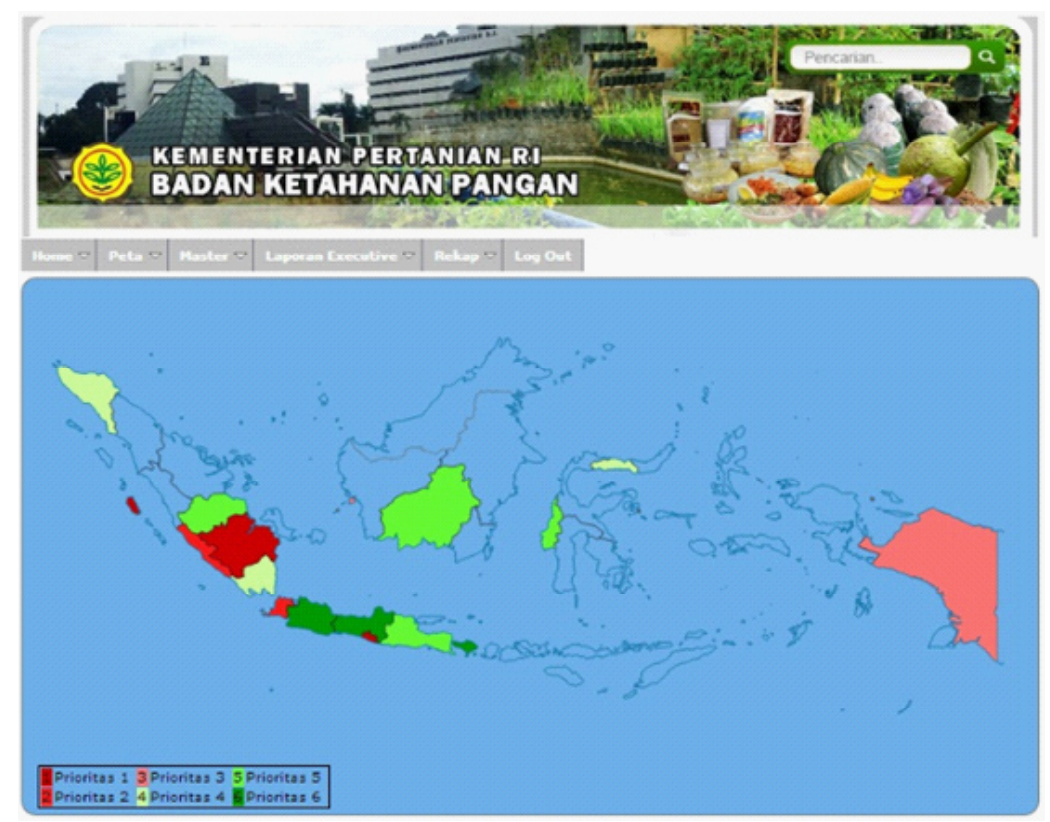

Fig. 5: Map of food vulnerability

(Source: food availability, May 2012)

On figure 5 can be seen region that is included in:

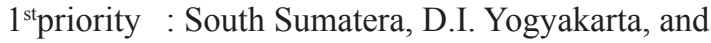
West Sumatera

$2^{\text {nd }}$ priority : Banten and Bengkulu

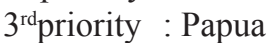

$4^{\text {th }}$ priority : Gorontalo and Aceh

$5^{\text {th }}$ priority $:$ Jambi, Central Kalimantan, East Java

$6^{\text {th }}$ priority : West Java, Central Java, Bali

Then the result of development of this system can give future prediction with growth percentage that can be obtained with this formula.

$R=\left[\frac{\sum \frac{P_{n}-P_{n}-1 \times 100 \%}{P_{n}-1}}{n-1}\right]$
Description:

$\mathrm{R}$ = average of growth (\%) during projection period

$\mathrm{P}=$ Data in year

$\mathrm{n}=$ the amount of year

$P t=P_{0}[1+R]^{n-1}$

Description:

$\mathrm{Pt}=$ data of year that is projected

Po $=$ data of initial year

$\mathrm{R}=$ average of growth (\%) in previous period

$\mathrm{n}=$ the amount of projection year

(Source: Nur ImdahMinsyah, 2006) 
The result of projection within period of next three years can be seen on figure 6 , where historical data that is used is data from 2001 till 2013. So that it can predict food security in each region in future. In this research, it gives prediction of condition of food security in next 3 years, which are 2014, 2015 and 2016.

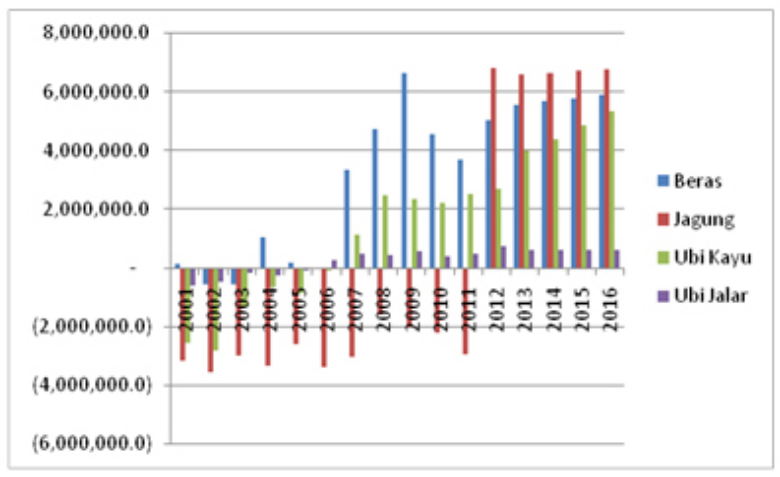

Fig. 6: Prediction of availability in next 3 years

(Source: data of food availability 2001-2013)

The final result of development of this information system also provides system of decisionmaking support that can be seen on figure 7 for the architecture.

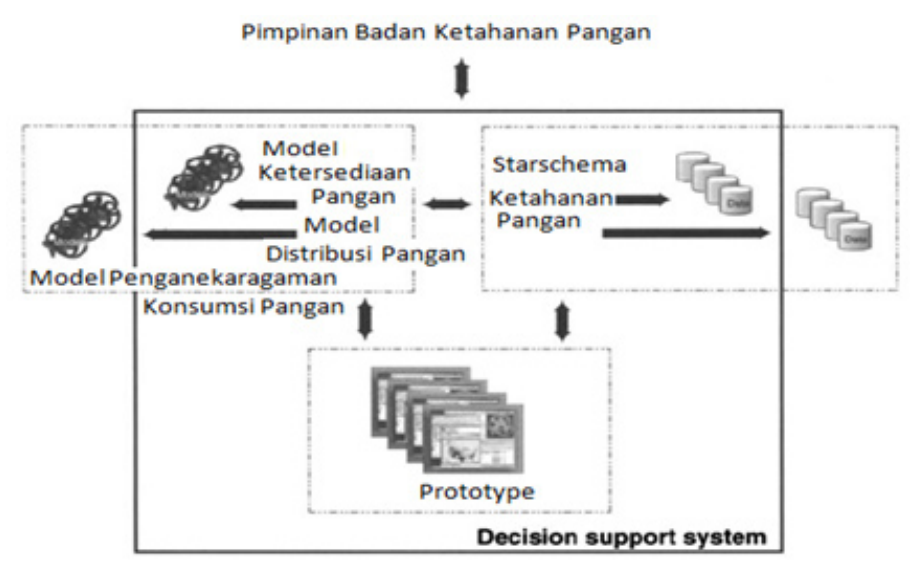

Fig. 7: Architecture of decision-making support system

The result of evaluation of system development using pre-post test where each chairman that is in each field that is asked to fill the questionnaire before and after the development of information system that is done. The questions that are asked in the questionnaire before and after are same. The result of questionnaire data can be seenin table 4 .
Table 4: Criteria of frequency

\begin{tabular}{lcccc}
\hline & Disagree & $\begin{array}{c}\text { Less } \\
\text { agree }\end{array}$ & Agree & $\begin{array}{c}\text { Strongly } \\
\text { agree }\end{array}$ \\
\hline Pre & 60 & 131 & 94 & 72 \\
Post & 15 & 44 & 118 & 179 \\
\hline
\end{tabular}

If it is seen in form of graphic like is shown on figure 8 .

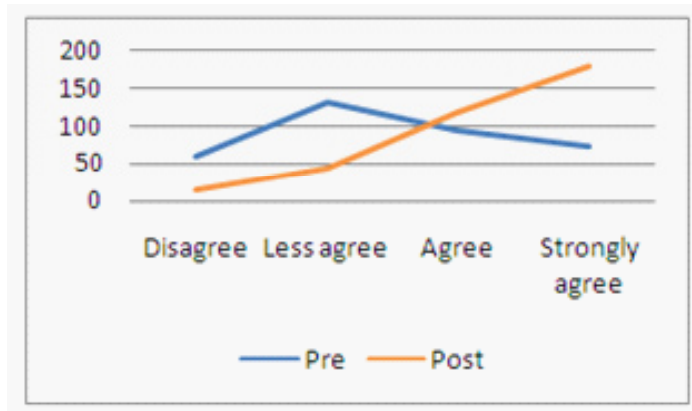

Fig. 8: The result of pre-post test

\section{CONCLUSION}

From the result of development of food security information system based on business intelligence, it can be concluded that:

1. From analysis that is done in internal and external environment, it is found problem faced by chairman of Food Security Agency especially in getting information related to region experiencing food vulnerability, as the effect of difficulty in accessing food from food sources and distributing it to society. However by developing this food security information system based on Business Intelligence, chairman can easily obtain that information through dashboard panels that have been made. Thus, chairman can immediately give special treatment in mitigation and recovery a region experiencing food vulnerability.

2. By developing information system based on this business intelligence, chairman can obtain fast, precise and real time information about food security. Where that information is used by chairman in making program plan, determining target, strategy and intervention of food vulnerability.

3. This development of information system can be used by chairman in giving decision to immediately give several types of help in accordance with food need in local area through available distribution lane quickly and precisely in a case of a region experience food vulnerability. 
So that the development of system doesn't only stop in here, then writer suggests several suggestions, which writer hopes this information system that has been develop can help more chairman more carefully. Here are several suggestions from writer:

1. Giving full support for implementation of food security information system that has tested its prototype.

2. Doing development of information system of food reserve, so whenever chairman can predict region that will experience food vulnerability, chairman can give decision related to usage of that food reserve.

3. Developing information system of price stability that may be one of the causes of food vulnerability as effect of price that often increases suddenly and people in middleloweconomy class become hard in getting food.

4. Developing food security information system, where the indicatorfrom this information system related with the amount of adequacy nutrient that has to be fulfilled by society.

5. Implementing development of food security system to mobile so chairman can obtain information easier. Implementing to mobile can be applied on mobile with android, IOS and blackberry platform.

\section{REFERENCES}

[1] C. Olszak, "The Business Intelligence - based Organization - new Chancesand Possibilities, "Proquest, pp. 242-249, 2012

[2] K. Gollapudi, Jangeti, K. Sunil , R. A. Kotapati, "analysis of using a business intelligence tool, "Business Intelligence Journal, vol. 5, pp, 406-409, 2012

[3] P. Kumar, "Impact of business intelligence systems in indian,"Business Intelligence Journal, vol. 5, pp. 358-366, 2012.

[4] C. Vercellis, Business Intelligence: data mining and optimization for decision making, Padstow, Cornwall, 2009

[5] F. N. Al-Aboud, "Strategic Information Systems Planning: A Brief Review,"International Jorunal of Computer Science and Network Security, vol. 11, pp. 179-183, 2011.

[6] A. Bhatnagar, "Strategic Information Systems Planning: Alignment of IS/IT Planning and Business Planning, "School of Computing and Information Technology Dissertation and Theses, pp. 1-77, 2007.

[7] C. Beveridge, "Aligning IT with Business Strategy, Guidelines for IT, Management number 273," The National Computing Centre Limited, pp.1-16, 2011, Available: www.ncc.co.uk

[8] T. M. Connolly and C. E. Begg, Database Systems: A Practical Approach to Design, Implememtation, and Management, 4th Ed., USA: Addison Wesley, Longman Inc., 2005.

[9] M. D. Dimitrov \& D. P. Rumrill, "Pretest-posttest designs and measurement of change" Speaking of Research, vol. 20, pp. 159-165, 2003.

[10] Departemen Pertanian RI and World Food Programme, D. K, Peta Ketahanan dan Kerentanan Pangan Indonesia. Jakarta: Dewan Ketahanan Pangan, Departemen Pertanian RI and WFP, 2009.

[11] W. V. Grembergen, "The Balanced Scorecard and IT Governance", Information Systems Control Journal, vol. 2, pp.40-43, 2000.

[12] S. Liu, A. B. Duffy, R. I. Whitfield, L. M. Boyle, "Integration of Decision Support Systems to Improve Decision Suppoert Performance,"Journal knoledge and information system, vol. 22, pp. $261-286$, 2009.

[13] K. H. Madsen, "Enterprise Architecture Implementation and Management: A Case Study on Interoperability," Proceedings of the 39thHawaii International Conference on System Sciences, vol. 4, pp. 71.3, 2006.

[14] J. Martin \& J. Leben, Strategic Information Planning Methodologies. $2^{\text {nd }}$ ed., NewJersey: PrenticeHall, 1989.

[15] J. A. O'brien, Pengantar Sistem Informasi: Perspektif Bisnisdan Manajerial, 12 $2^{\text {th }}$ ed., Jakarta: Salemba Empat, 2006.

[16] Pusat Distribusi, P, Pedoman Umum Pemantauan Distribusi Pangan. Jakarta: Badan Ketahanan Pangan Departemen Pertanian, 2009.

[17] F. Rangkuti, Analisis SWOT Teknik Membedah Kasus Bisnis, Jakarta: PT.Gramedia Pustaka Utama, 2006. 